\title{
COVID-19 and family planning in the Eastern Mediterranean Region
}

Azza Sarfraz, ${ }^{1,2}$ Zouina Sarfraz, ${ }^{1,3}$ Sameer Saleem Tebha, ${ }^{1}$ Namrata Hange, ${ }^{1}$ Kuchalambal Agadi, ${ }^{1}$ Alanna Barrios, ${ }^{1}$ Manish Kc ${ }^{1}$ and Gaurav Patel ${ }^{1}$

${ }^{1}$ Larkin Health System, South Miami, Florida, United States of America, ${ }^{2}$ Pediatrics and Child Health, Aga Khan University, Karachi, Pakistan. (Correspondence to: Azza Sarfraz: azza.sarfraz@aku.edu). ${ }^{3}$ Fatima Jinnah Medical University, Lahore, Pakistan.

Citation: Sarfraz A; Sarfraz Z; Tebha SS; Hange N; Agadi K; Barrios A; et al. COVID-19 and family planning in the Eastern Mediterranean Region. East Mediterr Health J. 2021;27(9):857-860. https://doi.org/10.26719/2021.27.9.857

Received: 17/11/20; accepted: 15/06/21

Copyright (C) World Health Organization (WHO) 2021. Open Access. Some rights reserved. This work is available under the CC BY-NC-SA 3.0 IGO license (https://creativecommons.org/licenses/by-nc-sa/3.o/igo).

\section{Introduction}

As of 3 February 2021, 5741533 confirmed cases of coronavirus disease 2019 (COVID-19) had been recorded across the 22 countries of World Health Organization's (WHO) Eastern Mediterranean Region since the first case was reported in the Region on 29 January 2020. Although the number of COVID-19 cases reported differs considerably between different WHO regions, the burden of COVID-19 on health care systems remains critical (1). The need to prioritize resources to protect against economic, health and social crises, and the reduction in in-person assistance and access to health services, could lead to a reduction in health services for family planning programmes. One of the most important features of family planning is the use of birth control methods which allows families to plan the desired number of children and birth spacing for women of reproductive age. We explore the family planning practices prevalent in the Eastern Mediterranean Region in the 21st century and access to these services during the COVID-19 pandemic.

\section{Contraceptive use in the Region}

One of the ways to reduce maternal and infant mortality and morbidity in a cost-effective manner is birth control. However, despite the efforts made, the evidence suggests that the prevalence of contraceptive use is low in the Eastern Mediterranean Region. Under-5 mortality remains high in the Region and accounts for nearly $15 \%$ of the global burden of under-5 mortality (2). While maternal mortality rates have been decreasing in the Region over the past 25 years, they are still high when compared with global trends. Some countries of the Region are classified as high-risk instability groups according to the Fragile State Index in $2020(3,4)$. To reduce the maternal mortality rate, practices such as birth spacing and use of contraceptive methods have shown satisfactory outcomes $(5,6)$. The use of contraceptive methods differs by sociocultural beliefs, thus the uptake of these methods differs across regions and has changed over the years (7). There are still unmet needs for and misconceptions about contraceptive methods, for example, about their mechanism of action or side-effects. Such misconceptions could be a main reason for the lack of use of contraceptive methods, even with the most popular methods such as oral contraceptive pills $(8,9)$.
Although measures to control rapid population growth were adopted by many countries as early as the 1950s, sub-Saharan Africa and the Eastern Mediterranean Region lagged behind $(10,11)$. At the same time, the maternal mortality and under-5 mortality rates in the Region are among the highest in the world, although they have been steadily decreasing since 2000 in many of the countries of the Region. However, Libya, Lebanon and Kuwait reported an increase in maternal mortality from 70,28 and 10 per 100000 live births respectively in 2000 to 72,29 and 12 per 100000 live births in 2017 (12). Under-5 mortality has shown a steady decline in all countries of the Region (13).

Today, the two most common methods of contraception in the Region are the pill (10.5\%) and intrauterine device $(9.5 \%)$ (14). Family planning is crucial for the health of women and their families, and it can accelerate a country's progress toward reducing poverty and achieving development goals. Unintended pregnancies are widespread in the Region, placing a burden on individuals, families, health systems and socioeconomic development $(14,15)$. The need for family planning supplies and services is increasing throughout the Region in part because of the rise in the number of women of reproductive age and increasing use of modern contraceptives $(14,15)$.

\section{Effect of COVID-19}

In March 2021, a United Nations survey in 115 low- and middle-income countries reported that about 1.4 million unwanted pregnancies might have occurred as a result of the disruptions to health care delivery caused by COVID-19 (16). While there have been few published data on these outcomes during the COVID-19 lockdowns, a prospective observational study noted that institutional childbirth decreased by more than half during the lockdown, with increased institutional stillbirths and neonatal deaths (17).

The COVID-19 pandemic has led to the postponement of planned permanent contraception procedures (e.g. tubal ligation and vasectomy) due to the need for resource allocation to COVID-19 patients, the infectious risk from intubation and extubation in hospital settings, and the theoretical infectious risk from aerosolization of surgical smoke during laparoscopy (18). While awaiting surgery for permanent contraception, these women are at risk of 
unintended pregnancies if not using an effective method of birth control. This suggests the need for reminders and counselling for such women on other effective contraceptive options by direct or virtual encounters. Importantly, the contraceptive trends demonstrate that the use of temporary and long-acting reversible contraceptives is higher than permanent methods of contraception (19). Couples who are waiting for provision of contraception should be reminded to use an effective, reversible method of contraception at this time as the pandemic has limited health care accessibility (20).

The decline in the prevalence of contraceptive use due to COVID-19 disruptions among women of reproductive age (15-49 years) is estimated to be $10 \%$ for each modern method and $20 \%$ for female and male sterilization (18). Rates of female sterilization have decreased in the Eastern Mediterranean Region (21). Previous disease outbreaks, such as Zika virus, have provided evidence of overloaded health services that limit women's access to pre- and post-natal health care, and contraception (22). Existing low use of health services for permanent contraception compounded with compromised access to family planning services may lead to an increased the number of unintended pregnancies and unsafe abortions thus adversely affecting maternal and neonatal health (23). Ensuring that people have access to contraceptive services will reduce avoidable pressures on the health system to manage the consequences of unintended pregnancy and future detrimental consequences of population growth.

\section{Family planning provision in the Region}

In Saudi Arabia, where most health services (75\%) are provided through government agencies, disruption due to COVID-19 might affect access to free contraception services (24). Qatar has one of the best health care services in the Region and citizens receive free or subsidized health care services in the public health care system. Higher-priced private care is also available for people desiring faster or more specialist treatment (25). Despite the fact that Qatar's public health department prioritizes free family planning services, the COVID-19 pandemic has affected access to these services (26). The advanced state-funded health care system in Kuwait also provides free treatment to citizens while expatriates pay nominal fees for non-emergency health services and government-subsidized medications (27). Health care services in Pakistan are provided by three-tiered public health care services and efficient private institutions, through ownership of the provincial government $(28,29)$. All of Pakistan's provinces have forwarded costed implementation plans for enhancement of family planning status and have formed family planning task forces incorporating public and private stakeholders. Each province is using local resources and training existing personnel to help increase the use of contraceptives. In addition, to promote the acceptability of family planning, the government is collaborating with men and religious leaders as part of its social mobilization efforts (30). In Lebanon, the economic collapse prior to the COVID-19 pandemic has impacted the healthcare sector, which is working at suboptimal capacity due to the pressure on the healthcare system (31). Given the change in focus of primary health services due to the COVID 19 pandemic and the expected lack of support for and supervision of the health care system, delivery of family planning services may be adversely affected (32). For most of the countries of the Region, family planning services are provided by the government health care system free of charge or at subsidized rates. COVID-19 has increased the burden on government health care systems, which has affected the provision of non-emergent services such as family planning. Permanent contraception, especially surgical procedures, have been put on hold, thus likely increasing unintended pregnancies. Many of the countries that have expatriate populations are more likely to be affected because these populations have less access to health care sectors (33).

The adopted family planning strategies and health care systems throughout the Eastern Mediterranean Region seem to be unique with the lowest contraceptive prevalence rates (11). Certain countries with higher population growth such as Kuwait have a state-funded health care system, suggesting the multifactorial contributors to successful family planning. The methods adopted by couples are likely influenced by sociocultural practices and the health care infrastructure. Further studies are needed to understand the effect of COVID-19 on access to family planning services across the Region. Strategies are needed to address the rise in the annual population growth in 2021 following COVID-19.

\section{References}

1. Al-Mandhari AS, Brennan RJ, Abubakar A, Hajjeh R. Tackling COVID-19 in the Eastern Mediterranean Region. Lancet. 2020;396(10265):1786-8. https://doi.org/10.1016/So140-6736(20)32349-7

2. Bhutta ZA, Belgaumi A, Rab MA, Karrar Z, Khashaba M, Mouane N. Child health and survival in the Eastern Mediterranean region. BMJ. 2006;333(7573):839-42. https://doi.org/10.1136/bmj.38979.379641.68

3. Asmri M Al, Almalki MJ, Fitzgerald G, Clark M. The public health care system and primary care services in Saudi Arabia: a system in transition. East Mediterr Health J. 2020;26(4):468-76. https://doi.org/10.26719/emhj.19.049

4. $\quad$ Fragile States Index - annual report 2020. Washington, DC: The Fund for Peace: 2020 (https://fragilestatesindex.org/wp-content/uploads/2020/05/fsi2020-report.pdf, accessed 17 August 2021). 
5. Ahmed S, Li Q, Liu L, Tsui AO. Maternal deaths averted by contraceptive use: an analysis of 172 countries. Lancet. 2012;380(9837):111-25. https://doi.org/10.1016/S0140-6736(12)60478-4

6. Stover J, Ross J. How increased contraceptive use has reduced maternal mortality. Matern Child Health J. 2010;14(5):687-95. https://doi.org/10.1007/s10995-009-0505-y

7. World family planning 2017 - highlights. New York: United Nations; 2017:43. (https://www.un.org/development/desa/pd/sites/ www.un.org.development.desa.pd/files/files/documents/2020/Jan/un_2017_worldfamilyplanning_highlights.pdf, accessed 1 March 2021).

8. Albezrah N. Use of modern family planning methods among Saudi women in Taif, KSA. Int J Reprod Contracept Obstet Gynecol. 2015;4(4):990-4. http://dx.doi.org/10.18203/2320-1770.ijrcog20150412

9. Al Sheeha M. Awareness and use of contraceptives among Saudi women attending primary care centers in Al-Qassim, Saudi Arabia. Int J Health Sci (Qassim). 2010;4(1):11-21.

10. Cleland JG, Ndugwa RP, Zulu EM. Family planning in sub-Saharan Africa: progress or stagnation? Bull World Health Organ. 2011;89(2):137-43. https://doi.org/10.2471/blt.10.077925

11. Shrestha BD, Ali M, Mahaini R, Gholbzouri K. A review of family planning policies and services in WHO Eastern Mediterranean Region Member States. East Mediterr Health J. 2019;25(2):127-33. https://doi.org/10.26719/emhj.18.023

12. The World Bank Data. Maternal mortality ratio (modeled estimate, per 100 ooo live births) [internet]. Washington, DC: The World Bank; 2019 (https://data.worldbank.org/indicator/SH.STA.MMRT, accessed 1 March 2021).

13. The World Bank Data. Mortality rate, under-5 (per 1000 live births) [internet]. Washington, DC: The World Bank; 2019 (https:// data.worldbank.org/indicator/SH.DYN.MORT, accessed 1 March 2021).

14. Contraceptive use by method 2019. New York: United Nations; 2019. (https://www.un.org/development/desa/pd/sites/www. un.org.development.desa.pd/files/files/documents/2020/Jan/un_2019_contraceptiveusebymethod_databooklet.pdf, accessed 1 March 2021).

15. Bellizzi S, Mannava P, Nagai M, Sobel HL. Reasons for discontinuation of contraception among women with a current unintended pregnancy in 36 low and middle-income countries. Contraception. 2020;101(1):26-33. https://doi.org/10.1016/j.contraception.2019.09.006

16. Impact of COVID-19 on family planning: what we know one year into the pandemic [Internet]. New York: United Nations Population Fund; 2021. (https://www.unfpa.org/sites/default/files/resource-pdf/COVID_Impact_FP_V5.pdf, accessed 1 March 2021).

17. Ashish KC, Gurung R, Kinney MV, Sunny AK, Moinuddin M, Basnet O, et al. Effect of the COVID-19 pandemic response on intrapartum care, stillbirth, and neonatal mortality outcomes in Nepal: a prospective observational study. Lancet Glob Health. 2020;8(10):e1273-81. https://doi.org/10.1016/S2214-109X(20)30345-4

18. Robinson EF, Moulder JK, Zerden ML, Miller AM, Zite NB. Preserving and advocating for essential care for women during the coronavirus disease 2019 pandemic. Am J Obstet Gynecol. 2020;223(2):219-20.e1. https://doi.org/10.1016/j.ajog.2020.05.022

19. Ali M, Folz R, Farron M. Expanding choice and access in contraception: an assessment of intrauterine contraception policies in low and middle-income countries. BMC Public Health. 2019;19(1):1-6. https://doi.org/10.1186/s12889-019-8080-7

20. World Health Organization Department of Reproductive Health and Research (WHO/RHR) and Johns Hopkins Bloomberg School of Public Health/Center for Communication Programs (CCP), Knowledge for health project. Family planning: a global handbook for providers (2018 update). Baltimore and Geneva: CCP and WHO; 2018 (https://apps.who.int/iris/bitstream/hand le/10665/260156/9780999203705-eng.pdf, accessed 1 March 2021).

21. Rahman A, Hamoda HM, Rahimi-Movaghar A, Khan M, Saeed K. Mental health services for youth in the Eastern Mediterranean Region: challenges and opportunities. East Mediterr Health J. 2019;25(2):80-81. https://doi.org/10.26719/2019.25.2.80

22. Darney BG, Aiken AR, Küng S. Access to contraception in the context of Zika: health system challenges and responses. Obstet Gynecol. 2017;129(4):638-42. https://doi.org/10.1097/AOG.0000000000001914

23. Tsui AO, McDonald-Mosley R, Burke AE. Family planning and the burden of unintended pregnancies. Epidemiol Rev. 2010;32(1):152-74. https://doi.org/10.1093/epirev/mxq012

24. Rahman R. The privatization of health care system in Saudi Arabia. Health Serv Insights. 2020;13:1178632920934497. https://doi. org/10.1177/1178632920934497

25. Goodman A. The development of the Qatar healthcare system: a review of the literature. Int J Clin Med. 2015;6(3):177-85. https:// doi.org/10.4236/ijcm.2015.63023

26. Al-Zaidan M, Ibrahim MI, Al-Kuwari MG, Mohammed AM, Mohammed MN, Al Abdulla S. Qatar's primary health care medication home delivery service: a response toward COVID-19. J Multidiscip Healthc. 2021;14:651-7. https://doi.org/10.2147/JMDH. S282079

27. Meleis AI. The health care system of Kuwait: the social paradoxes. Soc Sci Med Med Psychol Med Sociol. 1979;13A(6):743-9. https://doi.org/10.1016/0271-7123(79)90121-4

28. Chaudhry MA, Khan A. Shaping 21st century public health in Pakistan: an actionable agenda for achieving universal health coverage. Islamabad: Tabadlab Private Limited; 2020 (https://www.tabadlab.com/wp-content/uploads/2020/07/2020-07-14-TabadlabWorking-Paper-Public-Health-v11_Final-Publish.pdf, accessed 1 March 2021). 
29. Pakistan: Health service delivery [Internet]. Cairo: World Health Organization Regional Office for the Eastern Mediterranean (http://www.emro.who.int/pak/programmes/service-delivery.html, accessed 17 August 2021).

30. Pakistan. Commitment maker since 2021 [Internet]. Washington, DC: Family Planning 2020 (https://www.familyplanning2020. org/pakistan, accessed 17 August 2021).

31. Farha L, Abi Jaoude J. Lebanese healthcare system: how will the aftermath look? Cureus. 2020;12(9):e10270. https://doi. org/10.7759/cureus.10270

32. Kotlar B, Gerson E, Petrillo S, Langer A, Tiemeier H. The impact of the COVID-19 pandemic on maternal and perinatal health: a scoping review. Reprod Health. 2021;18(1):10. https://doi.org/10.1186/s12978-021-01070-6

33. Alkhamis AA. The association between insured male expatriates' knowledge of health insurance benefits and lack of access to health care in Saudi Arabia. BMC public health. 2018;18(1):1-9. https://doi.org/10.1186/s12889-018-5293-0 